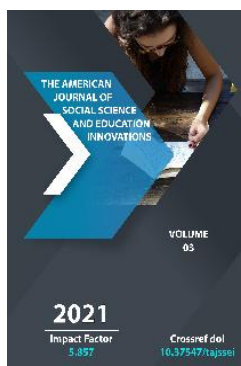

\title{
Experience Of Translating Historical Novels In Translation Studies
}

\author{
Erkinovna Khabibullaeva Makhliyo \\ Researcher, Tashkent State University Of Oriental Studies, Uzbekistan
}

\begin{abstract}
Journal Website:
http://theamericanjour

nals.com/index.php/taj

ssei

Copyright: Original content from this work may be used under the terms of the creative commons attributes 4.0 licence.
\end{abstract}

\section{ABSTRACT}

This article deals with the experience of translating historical novels in translation studies. It provides a comparative analysis of the specific methods of the Uzbek national school of translation studies and the world schools of translation. Moreover, the genesis of translation of Uzbek historical novels, methods of translation, especially the problem of technique in the translation into English, and certain peculiarities of translating historical works are studied here on a scientific basis. As a result, a number of scientific and practical recommendations are given to improve the mechanisms of forming professional competence in the practice of translating historical novels, with the experimental trends of world translation schools taken into account.

\section{KEYWORDS}

Translation process, translation of historical novels, cultural relations, national literature, foreign literature, professional competence of translators.

\section{INTRODUCTION}

After the acquisition ofindependence, the establishment and development of political, economic and cultural ties with different nations have become the demand of the time in Uzbekistan. And the role of translation is extremely important in strengthening the links of friendship and cooperation between the countries of the world. Besides, in the course of this process the Uzbek people and the people from foreign countries become acquainted with each other's life, history, culture, art and literary masterpieces. Currently, there is a growing interest and respect for Uzbekistan on the international 
arena. Today, the Republic of Uzbekistan occupies a worthy and strong place in the international community thanks to its great achievements attained in a short historical period, the spiritual roots, unique customs and traditions of our people, in short, the Uzbek character and Uzbek nature. Quite naturally, the world community wants to find answers to a wide spectrum of questions associated with our country, which are of great interest to them. And one of the best ways to do so is through our historical and modern literature.In recent years, a lot of opportunities have appeared to translate the best examples of Uzbek national literature into foreign languages and, on this basis, to demonstrate the mode of life and human qualities of our people. Let it be mentioned in this regard that significant gains have been achieved in the field of literary translation during the years of independence. In particular, both the translation into the Uzbek language of Western literary works, and the translation into Western languages of Uzbek masterpieces have become an integral part of the active literary process. The works of talented Uzbek writers were translated and published in English and other foreign languages in a short period of time, and these works were warmly welcomed by foreign readers. And historical novels by our writers occupy a special place among these translated works. It should be said here that our national school of translation studies does not have a sufficient experience of translating historical novels, but it does have a strong potential in this sphere. In translation studies, all nations have developed their own schools of translation of historical novels. It is very important to translate historical novels, because this genre of literature reflects the history, moral values, unique spiritual heritage and national spirit of people best of all. The Uzbek historical novels translated into foreign languages play a significant role in acquainting the international community with the national values of the country's inhabitants.

It is necessary to stress in this context that the process of translating historical novels has a higheducational, political, ideological and aesthetic significance in translation studies. This requires looking at the literary translation process as a great and serious creative activity. Taking into consideration its utmost significance and peculiarity, a number of practical measures should be undertaken to improve both the quality and a scientific level of translated works, as well as to accelerate the transition from foreign languages to Uzbek and from our native language to foreign languages. In the past few years, a number of the best examples of our national historical novels elucidating the lifestyle and human qualities of the Uzbeks have been translated into foreign languages. But, unfortunately, we have not been able to achieve any visible practical results in this field yet. The reason of this failure lies in the fact that in the past Uzbek historical novels were translated into other languages, mainly through a third language, mainly Russian. While appreciating the great work done in this direction, the need to intensify efforts in translating the most advanced national literary works directly from our native language into Western and Eastern languagesbecomes a matter of great urgency.

\section{MATERIAL AND METHODS}

The main condition for achieving a good level of adequacy in the translation of historical novels is the ability to fully reflect the artistic originality of the original, its national characteristics as well as the author's individual creative style. The translator's good command of the source language, plus his deep perception of such important factors 
aspeculiarities of the author's manner of writing, the special features of boththe text and the context will be indispensable in meeting a number of challenges to ensure the required adequacy. "The best way to know more aboutany nation is to learn its language. It should not be forgotten that translation is a method of work that is done out of necessity and requirement"[1]. Hence, it is difficult to perform an artistically perfect translation of a literary work without knowing the language of the original.

In translation studies, the process of translating samples of Western literature into the Uzbek languagenoticeably accelerated in the twentieth century. As for the translation of historical novels into our national language, a collection of such works by Western writers were translated and published in Uzbekistan in different years. In addition, many novels and short stories by T. Dreyzer, V. Irving, several novels by F. Cooper, dozens of attractive works by J. London, poetry and prose, as well as publicist works of such writers as E.Po, J.Rid, H.Fast, J.V.Shults etc. reached the hands of Uzbek readers. They enjoy a variety of new styles and trends in the world literature introduced by Mark Twain and Ernest Hemingway. As for the issue of translation from the original, the translator $\mathrm{S}$. Siddiq, who understood the need for this type of translation as far back as the 1930s, resorted to direct translation from English. Unfortunately, after putting forward a given initiative, S. Siddiq was submitted to repressions, followed by a long period of stagnation in the history of direct translation. A more serious approach to direct translation was undertaken almost four decades later - in 1972, by Abdukahhor Iminov, a talented Uzbek translator, who translated and published a number of stories by American writers directly from English. However, a number of complex issues surrounding the re-creation of the author's style in the processes of direct and indirect translation, the restoration of the integrity of the literary work's content and form, as well as the reflection of national terms and specific aspects in historical novels are still studied insufficiently. Figuratively speaking, the topical task of translating English literature directly from the original isat the crossroads.

It is no coincidence that this article is devoted to the current urgent problems of the theory and practice of translating historical novels in translation studies today. In translation studies, the analysis of certain traditions of translating historical novels focuses on the scrupulous investigation of tasks such as the reflection in translation of the national psyche, content and unity of form of the original etc. At the same time, the experience of direct translation of the afore-mentioned historical novels from English into Uzbek and from Uzbek into English, as well as the translation of the same novels through the intermediate language are placed at the center of this analytic work.

\section{RESULT AND DISCUSSION}

The artistic comparative study of historical novels translated directly from the English language into Uzbek encompasses the following aspects: the assessment of achievements and shortcomings of such translation, and the thorough examination of advantages of direct translation without denyingthe great enlightenment importance of indirect translation in expanding the Uzbek reader's artistic taste and world outlook. One of the most complicated tasks facing translation studies is to determine the level of translation, at which the spirit of the intermediary language is not absorbed through analysis. The development of Uzbek 
literary relations with other nations thanks to translation has been analyzed by a number of researchers, including G. Salomov, N. Kamilov, J. Sharipov, H.Hamroev, E.Normamedov, N.G'iyosov, M.Baqoeva and K.Sidikov.Their research works are really noteworthy.

So far, a lot of translations and research have been carried out in the field of translation, because there are enough research objects and materials for this kind of scientific activity. Many books have been translated directly from the English language into Uzbek and from Uzbek into English. The issue of transition from English to direct translation into the Uzbek language has been partially addressed in a number of articles written by translation scholars and researchers [4]. In our opinion, due to the fact that the number of direct translations is less than that of indirect translations, the "problems" inherent in indirect translation practices have been studied too much, while the issues of direct translation from the original have been neglected and the subject has not been studied in detail. Moreover, in the direct translation from the English language, issues such as the restoration of the original artistic style and the translator's skill have not been scrutinized in theory, and insufficient attention has been paid to the study of translating historical novels into the Uzbek language.

In translation studies, it is essential to reconstruct the artistic and methodological features, characterizing the translation of historical novels, in order to understand and interpret the original on this basis, as well as to study a whole set of issues that are closely linked with the determination of their adequacy to the original in the comparative study of direct and indirect translations of historical novels. So, it is necessary to identify the main stylistic aspects of historical novels, to study the methodological peculiarities of Uzbek translations and to compare their differences. In addition, it is important to study the interpretation of national terms, cultural and everyday identities, customs and traditions, feelings and experiences reflected in historical novels in Uzbek or in the language being translated, for example, in English. At the same time, the scientific analysis of the process of the original's adequate reconstruction and a palette of means of artistic expression used in translation on the basis of the comparative method also play a key role in the translation of historical novels. This, of course, makes it possible to observe to what extent the harmony of content and form has been preserved in the literary work during the comparison of direct and indirect translations in the practice of translating historical novels. In our opinion, in the direct translation of historical novels, both the adequacy and the translator's mastery serve as the main prerequisites for restoring the work's peculiar artistic style. As a telling example of this statement, let's take the first novel "O'tgan kunlar" by our great writer Abdullah Qadiri, published in the United States in the form of a book called "Bygone days". Translated by the renowned American translator and researcher Mark Edward Reese directly from the Uzbek language into English, this work, as noted above, has demonstrated the translator's excellent skill in restoring the authentic artistic style of a given historical novel. At the same time, when translating into the English language the national terms used there and restoring the artistic style of this work, Mark Reese accurately followed the rule of adequacy. It took him more than 15 years to translate this large-scale novel into English, with over 400 concepts and commentaries being written on the 660-page work to make it understandable to American readers. It is interesting to mention that the 
same work was translated into English by another translator, Carol Ermakova, a British literary critic, who translated more than 30 works of art. Being the first example of the Uzbek national school of historical novels, the book was translated with the support of the Karimov Foundation and published by the famous French Publishing House Nouveau Monde Editions. The translation was edited by Julie Weekenden. Unlike the US edition, the British version is not enriched with comments. Furthermore, it should be noted that in terms of experience of translating historical novels, the American translator's mastery in preserving the unique style of historical novels is higher than that of his British counterpart.

The experience accumulated by foreign translation schools also plays an important role in the translation of historical novels in translation studies. At the same time, it is important to study the specific translation methods developed by Western writers, to thoroughly investigate the genre features of Western novels, to analyze the comparison between their interpretations in the original languages and the translation of historical novels into different languages. What is necessary to underline here is that in the translation of Western historical novels and cultural and everyday features of the Uzbek national environment, or in the creation of English adequacy of national terms when translating Uzbek historical novels into the English language,the need for translation is now less widespread in translation. Because, in such a case, it is quite natural that the influence of the intermediary language in determining the degree to which the translated work is adequate to the original is greater. It is known from research in the field of translation studies that a lion's part of confusion in translation, which significantly impairs the translator's literary translation expertise, comes from the mediating language. For example, if we look at the history of literary translations from English, from the 1930s onwards, the works of English literature were translated from Russian, not Turkish, as they had originally been. A. Qahhor, who analyzed the state of literary translation thirty or forty years ago, noticed in particular: "We always say that there should be a translator who can translate from the original. But we don't have so many translators right now. Why should we now be deprived of the joy of reading national literature in Russian? ". The writer, who translates directly from the original, does not face additional obstacles in conveying the style, meaning and national spirit of the work. The translator, who relies on the intermediary language, is also limited in his ability to work on the original. We think therefore that the transition from indirect translation to direct translation in accordance with the demand of the time in Uzbek translation practices is one of the most important tasks facing our national translation studies. It should also be noted that in recent years a series of attempts have been made to move from indirect translation to direct translation of historical novels. The transition to direct translation will make it possible to eliminate some of the shortcomings that besieged previous translations. In this case, through a direct translation, the translator can fully reflect in his translation such essential things as the original narrative intonation, the emotional mood and world outlook of the author of the work being translated. In the words of K. Chukovsky, "The translator's calm ear undermines the methodological value of the work" . In this sense, the translator's main task is to invent new methods and forms of translation, because the writer is more eager to create new ones than to use the methods 
tested in every new work. Hence, the variability in literary traditions should not be left out of the translator's perspective either.

The issue of translating national terms in historical novels is analyzed by a number of outstanding scholars such as S. Vlakhov, S. Florin, A.V Fyodorov, V. Vinogradov, I. Kashkin and $\mathrm{V}$. Komissarov using the translation of realities. The necessity to preserve the originality of art in the translation of historical novels stems from the problem of reflecting the national identity of the original work. Words denoting objects, concepts and events specific to a particular nation allow the author to express the material and spiritual life of the characters he describes in a real, national form, more precisely. These words constitute one of the main means of defining the work of art's national character. The adequate interpretation in translation of the words, which express the national identity of different nations, is one of the most difficult aspects of such a complex problem as the restoration of the original's national character in a foreign language. In Salomov's words, "It is impossible to preserve all the elements of historical and national identity in the original, but it is necessary to keep among them such that, as a result, the reader will have an idea of the historical and national environment" [8]. One of the national peculiarities of historical novels is that the author makes extensive use of religious and mythical realities in his works for a specific artistic purpose. Since these realities have their own artistic function in the story, the translator must be careful when translating them into English or Uzbek.

The creator must act according to the degree to which the Uzbek or English reader is aware of the history, images and specific religious concepts. It is because, as S. Vlakhov and S. Florin noted, "Translation is made for "its"reader, if the realities brought to the text in such a way are beyond the reader's comprehension, then the communicative purpose of translation is not realized" . The opinion of the researcher $\mathrm{N}$. Dosbaeva is a clear proof of this. According to N. Dosbaeva, "There are factors that determine the national character of the work, which are related to the psychology and spiritual qualities of people. The fact that the English form "you" is the only equivalent in Uzbek for both "sen" and "siz" often requires an appropriate contextual action. In many cases, we see that the Uzbek translator followsthe Russian translator using an action that is completely incompatible with the culture of the target language. In the Russian language, it is natural for people to address adults as "you". It would be very appropriate for the translator to use the "you" form of the reference here. In order to convey the tone of the characters' speech, it is advisable to include some Uzbek phrases in the translated text that the reader can digest, because every student understands within the norms of their language." In general, as mentioned above, the problem of style also plays an important role in the translation process. After all, the essence of translation is to find new translation methods to ensure the integrity reflected in the original.

In conclusion, it can be resumed on the basis of analysis of the experience gained in the field of translating historical novels, that due to the lack of competent translators who can translate directly from English into Uzbek or from Uzbek into English, a majority of translations were accomplished by means of intermediate languages. We can say that this has led to the underdevelopment of national translation studies. However, it should be noted that among the indirect translations there are many works that are close to the original. This fact is undeniable indeed. It is 
known from the experience of translating historical novels that the problem of style in the translation of the work plays an important role in the enrichment of national translation studies. In recent years, the process of translating historical novels from the Uzbek language directly into English or from the English language into Uzbek has become more widespread, which requires a greater deal of scientific research on current issues in this area.

\section{REFERENCES}

1. Salomov $\mathrm{G}^{\prime}$. Language and translation. $-\mathrm{T}$ .: Fan, 1966. - p145.

2. Golden sarob. - $\mathrm{T}$.: Literature and Art Publishing House, 1974. -p. 264.

3. Shukrullaeva S. I. The rebirth of the divine svoeobraziya "Baburname" in the ego of the English translation. (Dj. Leydena, U. Erskina and A. Beveridj): Author. diss. ... Kand. filol. science. - T., 1989. - 20 s; Sobirov M. Problems of restoring the author's style and art in the English translations of "Boburnoma". (Based on a comparative analysis of Leiden-Erskin, Beverij, and Texton translations): Philol. fan. nomz.... diss. - T., 2002. - p132.

4. Raxmonkulovna. M.R. "English - uzbek translation process and their analysis"WOS. International scientific research journal ISSN 2772 6-0979 Volumez Issue 5, may, 2021.

5. Iminov A. Translation and lexical possibilities // The art of translation. - 1973. - pp263-274.

6. Qahhor A. The Concerns of Translation // The Art of Translation. - T : G. Gulom Publishing House of Literature and Art, 1973. - p10.

7. Erkinovna M. Kh. Some comments on the use of the uzbek language in society. 2020;
19(4): pp.757-764 http://ilkogretim online.org/index.php?mno=51124

8. Chukovskiy K. Izb.truda - S. pp170-171.

9. Salomov G'. Fundamentals of translation theory. - T .: Teacher,1983. -p104.

10. Dosbaeva Nargiza Turgunpulatovna. Restoration of artistic style in direct translation (on the example of translation of American stories) PhD..... - T., 2011 p26.

11. Raxmonkulovna. M.R. On the process of translation from English into Uzbek and its essence. International journal of discourse on innovation, integration and education . ISSN: 2181-1067. Volume: 02 Issue: 02 | 2021 pp. 297-300.

12. Raxmonkulovna, A. M., Ilxomqizi, S. S., \& Xaitbayevna, N. M. (2020). Principles of understanding a positive language in translation (in act of the Agatha Christies works). ACADEMICIA: An International Multidisciplinary Research Journal, 10(4), pp156-158. 